\title{
Increasing Tax Morale by Reward and Punishment Mechanism to Support Green Economy and Sustainable Development in the Tax Sector
}

\author{
Abdul Rahman \\ \{rhnoke@gmail.com\} \\ STIA LAN Bandung, Indonesia
}

\begin{abstract}
Taxation is an important source of revenue for a country. Unfortunately, countries by tax system still have problem with tax compliance because low tax morale and low tax sanction enforcement. This condition invites my attention to conduct research related to the effect of tax sanction by combining reward and punishment against tax morale in order to increase tax compliance. Research is undertaken through online survey, As a result, respondents agree toward reward and punishment mechanism in the tax sanction and this mechanism can enhance the tax morale. Therefore, I recommend the implementation of tax sanction in the form of easiness (reward) and uneasiness (punishment) in obtaining public services. It is considered more humane than imprisonment sanction to people, who have contributed to the country by taxes paid and more smooth to increase tax morale, so that the green economy and sustainable developments in the tax sector can be realized.
\end{abstract}

Keywords: Tax Compliance, Tax Morale, Tax Sanction, Reward, Punishment

\section{Introduction}

Tax grows as a foundation for the government income and becomes the main tool for development and reducing dependence on debt (OECD Economic Outlook 2011). Its important role for the revenue state makes up more than 94 percent of the countries in the world impose taxes for their citizens. Research in many developing countries has recently demonstrated that the tax can play a central role in the development of power of state and society. This is seen on two principles, namely the imposition of a tax as a negotiation process based on social contract (revenue-bargaining policy) and taxes for institutional development in order to strengthen the capacity of the state to perform its functions [1].

Therefore the government conducted improvements in all sectors of taxation, known as tax reform. In general, the tax reforms in Indonesia are undertaken by the spirit in enhancing the Indonesian tax system competitiveness, simplifying procedures, providing legal certainty and improving tax fairness. The study from Rahman [4] tried to assess the government as general strategy to increase tax compliance in Indonesia by focusing on public officials as represent of government. As a result, the study indicates the tax sanction and tax morale as the lowest assessment and low effect to tax compliance.

Therefore, the research objective is formulated as follows: To understand the effect of tax sanction (with reward and punishment as dimensions) on tax morale (by tax knowledge, 
understanding of rules, tax expectation as dimensions) including clarifying these dimensions as factors constructing the variables.

According to the aim, this study develops an instrument to explore the perception and to measure the effect of perception to answer research questions, namely:

a) What are the perceptions of taxpayers regarding reward and punishment as dimensions of tax sanction and tax knowledge, understanding of rules, \& tax expectation as dimensions of tax morale?

b) How do the dimensions of both tax sanction and tax morale construct these variables?

c) How do the perceptions of taxpayers regarding tax sanction affect the tax morale?

To answers these questions, the study comprises fourth parts. In the second part, the study describes the research method consisting of object of research, population and sampling, technique of data collection, data analysis technique, and instrument development. In the third part, the study presents the result and discussion. Finally, the study highlights the conclusion of study and proposes the potential avenues as recommendation including references.

\section{Research Method}

This study has the typology of causality, which means that the study will carry out testing of causality in the research by using the quantitative research to explain how the independent variables affect the dependent variable [11]. Therefore, this study only emphasizes to explore the causality of variables that have been formulated within the framework, in which primary data are collected by a survey method. In addition, a survey is conducted to see the condition of each variable and to determine the relationship between the independent variables and dependent variable. In general, the stages of survey consist of: 1) formulating the research problem and determining the purpose of survey; 2) defining the concepts and hypotheses including exploring the literature; 3) sampling; 4) developing a questionnaire; 5) conducting field work and collecting data; 6) processing data; and 7) analyzing and reporting data [13].

In the implementation, applying the quantitative method is translated into online survey. To test the measurement model and to analyze the effect of relationship and dimensions constructing variables, we utilized PLS analysis which is well suited for theory building and prediction [14]. SmartPLS version 2.0 (M3) was used to run the PLS analysis [15].

\subsection{Object of research}

In this study, objects of research consist of two variables, which are as follows: 1) tax sanction $(\mathrm{X})$ and 2) tax morale (Y). Furthermore, this study has two types of research variables, namely exogenous and endogenous variable. Exogenous variable in this study is tax sanction and the endogenous variable is tax morale. This study also classifies the variable research into latent variables and observed variable. Latent variables are not to be measured directly but are to be formed through several dimensions. In this context, latent variables consist of tax sanction and tax morale. On the other hand, observed variables are dimensions measured, in which their data will be found through a survey instrument. In this study, observed variables involve reward, punishment, tax knowledge, understanding of rules, and tax expectation.

\subsection{Population and sampling}


The population in this study is the individual taxpayer for the personal income tax in Indonesia. The sample constitutes a part of the population, as a source of data and can represent the whole population [16]. In this study, sample is attainted by the purposive sampling technique, with the following criteria: 1) the individual taxpayer as an employee in the public sector consisting of government and state enterprise employees, and 2) the individual taxpayer as an employee in the private sector. The data required in this research is the primary data. Respondents for the online survey consist of government employee, state enterprise employee, and private sector employee.

\subsection{Technique of data collection}

Nazir [17] says that the data collection technique is a tool required in collecting data of both numbers, written information, oral information and various facts related to the research focus. In this study, I use the online survey as the main techniques of data collection. In addition, a survey is conducted to see the condition of each variable and to determine the relationship between the independent variables and dependent variable. In this study, I create a questionnaire and I distribute it to respondent consisting of government, state enterprise, and private workers by online with the special site. In general, online survey covers questions related to identity of respondent, tax morale, reward, and punishment.

\subsection{Data analysis technique}

Data analysis is a series of activities performed after the data from all respondents and other sources collected to determine the relationship between variables (variables $\mathrm{X}$ and $\mathrm{Y}$ ), so that it can be concluded whether the hypothesis is accepted or rejected. In general, process of data analysis covers coding, editing, data processing, and data analyzing. In this study, besides conducting descriptive analysis to see the characteristics of respondents and the mean and frequency of each variable, data is also analyzed by Partial Least Square (PLS) analysis. In the implementation, descriptive analysis is realized by Qualtrics Software and verification analysis, consisted of assessing outer model and assessing inner model.

\subsection{Instrument development}

The survey was conducted by online using a questionnaire containing a list of questions related to the research objectives. Measurement of all variables was developed by using a Likert scale ranging from a scale of 1 (Strongly Disagree) to 5 (Strongly Agree). To create the questionnaire, I use the Qualtrics, online survey software.

\section{Result and Discussion}

\subsection{Results}

\subsubsection{Characteristics of respondents}


Online survey has undertaken within the period of April, 15 until Mei, 15 2015. I invite respondents by emails, Facebook, and other social media such WhatsApp and messenger. For entry, we provide site to access, namely: https://qtrial2014az1.az1.qualtrics.com/SE/?SID= SV_3JlwIkxL8ePBnO5

In that period, this study captures 244 respondents. Furthermore, I conduct verification to check the completeness of answers for each question. As a result, there are 189 respondents with the complete answer identified. Specifically, the study resulted that almost $70 \%$ of respondents are male; around $46 \%$ of respondents have Master Degree as the last education; almost $60 \%$ of respondent come from the civil servants of both central and local government; and respondents of this study come from 15 provinces of both as province of institution and domicile.

\subsubsection{Descriptive analysis}

In the aspect of dimension of tax morale, this study highlighted that a) respondents agree with the knowledge regarding with taxation (average 3.9 from 5); b) respondents stand in the neutral position and tend to agree about understanding of tax rules (average 3.4 to 5); c) respondents agree with expectations toward the implementation of taxation (average 3.6 to 5). Overall, I conclude that respondents agree that they have good tax morale (3.6) in the side of tax knowledge, understanding of tax rules, and tax expectations.

On the other hand, for dimension of tax sanction, this study found that respondents agree with applying rewards in taxation (by average 3.6 to 5) and respondents stand in the neutral position and tend to agree with applying punishment in taxation (by average 3.3 to 5). According to the averages, I conclude that respondents tend to agree (3.5) toward applying tax sanction in the side of reward and punishment.

\subsubsection{Verification Analysis}

SmartPLS ver.2.0 is used to obtain the general effect of tax sanction on the tax morale. I employ the result of online survey because data represent all taxpayers in Indonesia both taxpayers employed private and public sectors. In detail, the result can be shown as follows:

a) Assessing outer model (measurement of model)

The measurement of model or outer model is evaluated by convergent validity, discriminant validity, and composite reliability of dimensions.

b) Convergent validity

Convergent validity is assessed based on the correlation between item scores/component scores to construct scores were calculated by the PLS. The validity of dimension as constructing a variable is high when the level of correlation (loading factor) is more than 0.70 . However, if the value of correlation is among 0.50 to 0.60 , it is considered sufficient for the research development.

The test result of outer model can be seen in figure and table below: 


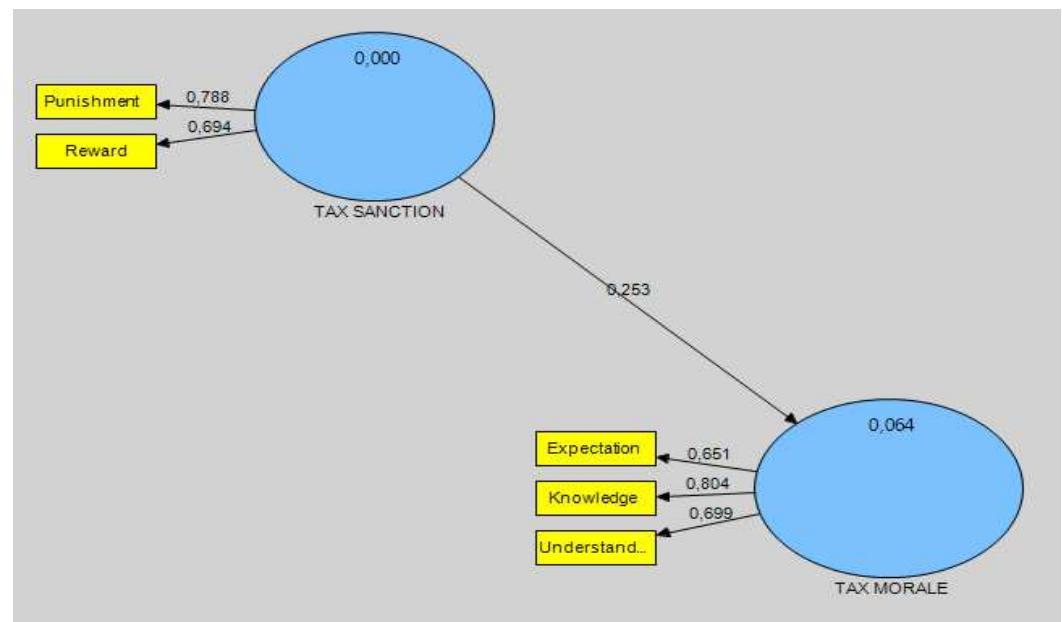

Fig. 1. the result of Algorithm PLS.

Table 1. Outer Loadings

\begin{tabular}{lcc} 
& Tax Morale & Tax Sanction \\
\hline Knowledge & 0.804 & \\
Understanding & 0.699 & \\
Expectation & 0.651 & 0.694 \\
Reward & & 0.788 \\
Punishment & & \\
\hline
\end{tabular}

The figure 1 and table 1 present that all dimensions have factor loading of more than 0.50 so it can be said that all dimensions have the convergent validity.

c) Discriminant validity

Test of discriminant validity is conducted by comparing the value of loading factor of dimensions of variable focused with the value of loading factor of these dimensions within the other variable.

Table 2. Cross Loadings

\begin{tabular}{lcc}
\hline & Tax Morale & Tax Sanction \\
\hline Knowledge & $\mathbf{0 . 8 0 4 0}$ & 0.1933 \\
Understanding & $\mathbf{0 . 6 9 8 9}$ & 0.2146 \\
Expectation & $\mathbf{0 . 6 5 1 0}$ & 0.0843 \\
Reward & 0.1728 & $\mathbf{0 . 6 9 3 9}$ \\
Punishment & 0.2023 & $\mathbf{0 . 7 8 8 4}$ \\
\hline
\end{tabular}

Table 2 shows that the value of loading factor of dimensions of tax morale is higher than the value of loading factor of dimensions of tax morale within tax sanction and vice versa. It means that dimensions of both tax morale and tax sanction have the discriminant validity.

d) Composite reliability 
A variable can be said to be reliable if the value is more than 0.60 . The result of reliability test presents that the variable of tax morale and tax sanction have the reliability because the internal consistency is greater than 0.60 (see table).

Table 3. Composite Reliability

\begin{tabular}{lc}
\hline & Composite Reliability \\
\hline Tax Morale & 0.7629 \\
Tax Sanction & 0.7101 \\
\hline
\end{tabular}

Referring the result of testing outer model, in which each dimension has convergent validity, discriminant validity, and reliability, we identify that dimension of reward and punishment constructs the variable of tax sanction [hypothesis 1 (H1) is accepted]. On the other side, tax knowledge, understanding of rules, and tax expectation also construct the variable of tax morale [hypothesis 2 (H2) is accepted].

e) Assessing inner model (structural model)

The test of inner model is conducted to examine the relationship between tax sanction (dependent variable) and tax morale (independent variable). By using SmartPLS ver.2.0, we obtain t-statistics that can be presented in the following figure and table:

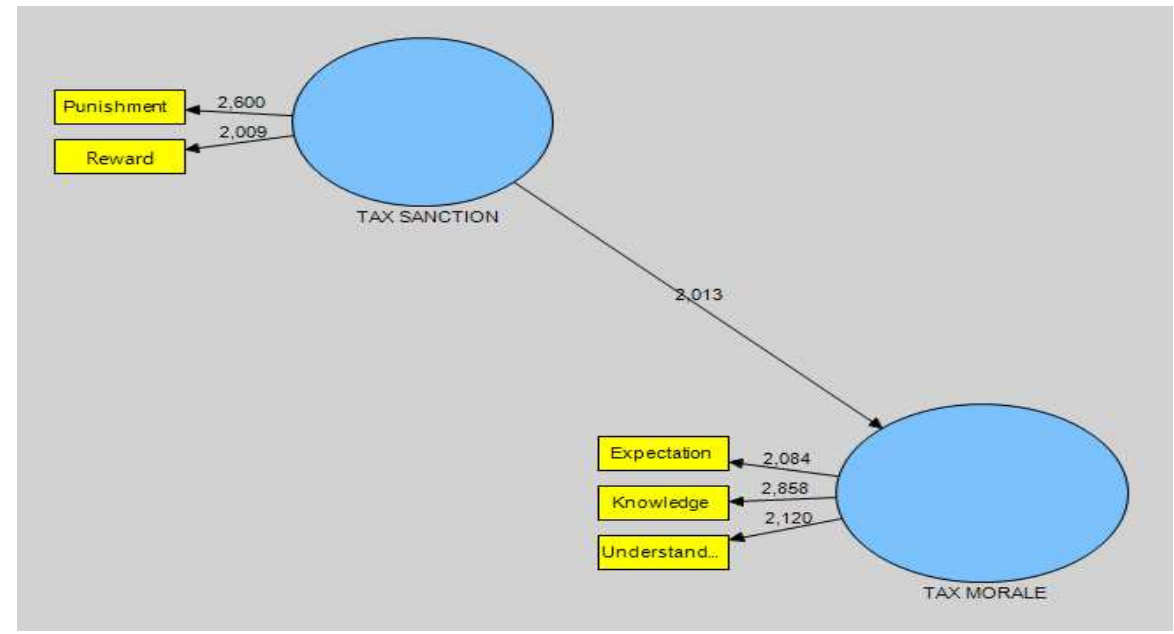

Fig 2. the result of algorithm PLS

Table 4. Value of t-table and t-statistics

\begin{tabular}{lcc}
\hline & t-table (critical point) & t-statistics \\
\hline Punishment -> Tax Sanction & 1.97273 & 2.600 \\
Reward -> Tax Sanction & 1.97273 & 2.009 \\
Tax Sanction -> Tax Morale & 1.97273 & 2.013 \\
Expectation -> Tax Morale & 1.97273 & 2.084 \\
Knowledge -> Tax Morale & 1.97273 & 2.858 \\
Understanding -> Tax Morale & 1.97273 & 2.120 \\
\hline
\end{tabular}

The figure 2 and table 4 indicate that the value of t-statistics for relationship between tax sanction and tax morale is 2.013 . This value is higher than the value of $t-$ 
table at 1.972. This result clarifies that tax sanction by dimension of reward and punishment is positively associated with tax morale by dimension of tax knowledge, understanding of rules, and tax expectation [hypothesis 3 (H3) is accepted].

The positive association provides the effect of tax sanction on tax morale of respondent. The value of effect can be demonstrated in the following table

Table 5. R Square

\begin{tabular}{ll}
\hline & R Square \\
\hline Tax Sanction & \\
Tax Morale & 0.0642 \\
\hline
\end{tabular}

The table 5 demonstrates that the effect of tax sanction on tax morale is 0.0642 , or 6.4 percent, while the 93.6 percent is explained by other variables outside the model.

\subsection{Discussion}

What are the perceptions of taxpayers regarding reward and punishment as dimensions of tax sanction, and tax knowledge, understanding of rules, \& tax expectation as dimensions of tax?

The online survey explores that almost $70 \%$ of respondents are male, in which around $46 \%$ of respondents have Master Degree as the last education and almost $60 \%$ of respondent come from the civil servants of both central and local government and rest from state enterprise employees and private sector. It means the survey cover all kinds of taxpayer. Furthermore, respondents of this study come from 15 provinces of both as province of institution and domicile. Descriptively, this study highlights that respondents agree with the tax knowledge (average 3.9) and stand in the neutral position about understanding of tax rules (average 3.4). Furthermore, respondents also agree with tax expectations (average 3.6). Overall, this result indicates that respondents agree toward tax knowledge, understanding of tax rules and tax expectation as dimensions of tax morale (average 3.6). Moreover, this study underscores that respondents agree with applying rewards in taxation (average 3.6). Then respondents stand in the neutral position with applying punishment in taxation (average 3.3). Overall, this study clarifies that respondents agree (3.5) toward applying tax sanction in the side of reward and punishment.

\section{How do the dimensions of both tax sanction and tax morale construct these variables?}

In verification, this study presents that all dimensions of both tax sanction and tax morale have factor loading of more than 0.50 . So it can be said that all dimensions have the convergent validity. This result is supported by the existence of discriminant validity assessed by looking at the cross loading between dimensions with their variables. In this context, this study reveals that the relationship of tax morale with its dimensions is higher than relationship between dimensions of tax morale within the variable of tax sanction and vice versa. It is mean that dimension of both tax morale and tax sanction has the good discriminant validity. Moreover, based on the reliability test, in which a variable can be said to be reliable if the value is more than 0.60 , the study shows that the variable of tax morale and tax sanction have the good reliability because the internal consistency is greater than 0.60 . Referring the result of testing outer model, in which each dimension has convergent validity, discriminant validity, and reliability, we identify that dimension of reward and punishment constructs the variable of tax sanction. Furthermore, the tax knowledge, understanding of rules and tax expectation also 
construct the variable of tax morale.

How do the perceptions of taxpayers regarding tax sanction affect the tax morale in order to support green economy and sustainable development in the tax sector?

This study explores the significance level of influence between dimensions \& variable and then between variables. As a result none of each relationship has a $t$-value under the $t$ table or critical point, Overall, these relationships provide the effect of tax sanction on tax morale is 0.0642 , or $6.4 \%$, while $93.6 \%$ is explained by other variables outside the model. Hence, this study, at least, clarifies that aforementioned perceptions of taxpayers regarding tax sanction through reward and punishment affect their tax morale. In this context, the existence of reward and punishment is to be increase tax morale, so that tax compliance to be better. The improvement of tax compliance can increase the government income, so that the support of green economy and sustainable development in the tax sector to be achieved.

\section{Conclusion}

The online survey shows the agreement of respondent in the implementation of tax sanction in the form of reward and punishment. Besides that, respondents also agree that the existence of tax knowledge, understanding of rule, and tax expectation influence their motivation to fulfill tax obligations (tax morale). The test of verification proves that each dimension constructs the variable. It means that reward and punishment construct tax sanction. Then tax knowledge, understanding rules, and tax expectation construct tax morale. These results rich our insight about factors affecting tax sanction and tax morale. Furthermore, this study also proves the role of tax sanction via reward and punishment in influencing and increasing tax morale. This is because result of study shows the existence of significant relationship and effect from tax sanction on tax morale of taxpayers.

Referring these conclusions, I generate the reward and punishment as the key factors for improving tax compliance through the role of tax morale. As implication, the future innovations should be conducted by changing the concept of tax sanction in the form of reward and punishment approach. Reward and punishment are carried out by providing ease and unease for taxpayer in getting public services such as obtaining a business license, a passport, a permit to build the house, bank loan applications, and others. It is considered more humane than imprisonment sanction to people, who have contributed to the country by taxes paid and smoother to increase tax morale so that the green economy and sustainable development in the tax sector could be achieved.

\section{References}

[1] D. A. Bräutigam, O. H. Fjeldstad, and M. Moore, Taxation and state-building in developing countries: Capacity and consent. 2008.

[2] C. Nasucha, Reform of Public Administration, Theory and Practice. Jakarta: PT Gramedia Widiasarana, 2004.

[3] Gunadi, "Reformasi Administrasi Perpajakan dalam Rangka Kontribusi Menuju Good Governance," Pidato Pengukuhan Guru besar Perpajakan, FISIP, Univ. Indones. Jakarta, 2004.

[4] A. Rahman, "How Do Public Officials Perceive Themselves as Taxpayers? A Study of Effect of Modernized Tax Administration System, Tax Sanction, Tax Service, and Tax Morale on Tax 
Compliance of Public Officials in Indonesia," 2017.

[5] R. Ilyas, Wirawan B.; Burton, Hukum Pajak. Jakarta: Salemba Empat, 2007.

[6] H. P. Arum, "Skripsi Pengaruh Kesadaran Wajib Pajak, Pelayanan Fiskus dan Sanksi terhadap Kepatuhan Wajib Pajak Orang Pribadi yang Melakukan Kegiatan Usaha dan Pekerjaan Bebas (Studi di Wilayah KPP Pratama Cilacap)," Publ. Fak. Ekon. Univ. Diponegoro, vol. 1, no. 2010, pp. 1-8, 2012.

[7] M. M. Ali, H. W. Cecil, and J. A. Knoblett, "The effects of tax rates and enforcement policies on taxpayer compliance: A study of self-employed taxpayers," Atl. Econ. J., vol. 29, no. 2, pp. 186-202, 2001.

[8] B. Nerrè, "The Concepts of tax culture," Annu. Conf. Tax. Minutes Annu. Meet. Natl. Tax Assoc., vol. 94, no. 2001, pp. 288-295, 2001.

[9] B. Torgler and F. Schneider, "Attitudes towards paying taxes in Austria: An empirical analysis," Empirica, vol. 32, no. 2, pp. 231-250, 2005.

[10] R. G. Cummings, J. Martinez-Vazquez, M. McKee, and B. Torgler, "Effects of tax morale on tax compliance: experimental and survey evidence," Berkeley Progr. Law Econ. Work. Pap. Ser., no. October, p. 37, 2006.

[11] J. W. Creswell and J. D. Creswell, Research design: Qualitative, quantitative, and mixed methods approaches. Sage publications, 2017.

[12] Sugiyono, "Metode Penelitian Kuantitatif, Kualitatif dan R\&D," Alf. Bandung, 2014.

[13] M. Singarimbun, Metode Penelitian Survai.pdf. 1989.

[14] C. M. Ringle, M. Sarstedt, and D. W. Straub, "A critical look at the use of PLS-SEM in MIS quarterly," MIS Quarterly: Management Information Systems, vol. 36, no. 1. 2012.

[15] C. M. Ringle, S. Wende, and S. Will, "SmartPLS 2.0 (M3) Beta," Hamburg, p. http://www.smartpls.de, 2005.

[16] S. Arikunto, Prosedur Penelitian Suatu Pendekatan Praktik. Jakarta: Rineka Cipta, 2006.

[17] M. Nazir, Metode Penelitan. Jakarta: Ghalia Indonesia, 2003.

[18] Sugiyono, Metode Penelitian Pendidikan Pendekatan Kuantitatif, Kualitatif, dan $R \& D$. Bandung: Alfabeta, 2009. 